\title{
Intas Freimanes devums latviešu valodas kultūras kā zinātnes nozares attīstība ${ }^{1}$
}

\section{Inta Freimanes's contribution to the development of Latvian culture of language as a branch of science}

\author{
Inta Urbanoviča \\ Latvijas Universitāte, Humanitāro zinātņu fakultāte \\ Latviešu un vispārīgās valodniecības katedra \\ Visvalža iela 4a, Rīga, LV-1050 \\ E-pasts:inta.urbanovica@lu.lv
}

Valodas kultūra ir viena no tām valodniecības nozarēm, kurā habilitētā filolog̣ijas doktore profesore Inta Freimane aktīvi darbojusies kopš 20.gs. 70. gadiem, un viņu pamatoti var uzskatīt par šīs zinātnes nozares izveidotāiju latviešu valodniecībā. Šì raksta mērķis ir aplūkot galvenos virzienus, kuros I. Freimane ir darbojusies valodas kultūras jomā, kā arī konspektīvi aprakstīt nozīmīgākos valodas kultūras teorijas jautājumus, kas ir aplūkoti valodnieces zinātniskajos darbos. Šī mērḳa sasniegšanai galvenokārt izmantota aprakstošā metode.

Savas pedagoǵiskās darbības laikā I. Freimane ir izstrādājusi augstskolām paredzētu mācību kursu, kurā iekḷauti galvenie valodas kultūras teorijas jautājumi, kā arī īpaša uzmanība pievērsta studentu patstāvīgajam darbam valodas prakses piemēru analīzēe un aprakstīšanā. Šì kursa pamatkoncepcija tiek izmantota arī mūsdienās. I. Freimane ir izveidojusi valodas kultūras teorijas pamatu, izmantojot čehu funkcionālās lingvistikas idejas. Svarīgākās valodas kultūras kā zinātnes atziņas ir apkopotas monogrāfijā „Valodas kultūra teorētiskā skatījumā” (1993), par kuru I. Freimanei piešķirts habilitētā filolog̣ijas doktora grāds. Valodniece ir nostiprinājusi termina valodas kultūra izpratni latviešu valodniecībā, pievērsusies tādiem jautājumiem kā nacionālās valodas polifunkcionālums, literārās valodas izpratne, literārās normas teorija, paralēlismu teorija u. c. Ilgstoši analizējot dažādas valodas prakses problēmas, I. Freimane ir savākusi apjomīgu ekscerptu kartotēku, uz kuras pamata izstrādāta detalizēta valodas prakses materiālu analīzes sistēma, kas piedāvā vienotu pārskatu par biežāk sastopamajām atkāpēm no literārās valodas normām visos valodas līmeņos.

Atslēgvārdi: Inta Freimane; valodas kultūra; literārā valoda; atkāpes no literārās valodas normām.

\footnotetext{
1 Raksta autore izsaka pateicību profesorei Intai Freimanei par sadarbību raksta tapšanā.
} 
Habilitētā filolog̣ijas doktore LU emeritētā profesore Inta Freimane ir strādājusi vairākās valodniecības nozarēs un devusi vērtīgu ieguldījumu latviešu valodniecības attīstībā. Viens no nozīmīgākajiem zinātniskā darba virzieniem ir latviešu valodas kultūras teorijas un prakses jautājumi, un I. Freimani pamatoti var uzskatīt par valodas kultūras zinātnes izveidotāju latviešu valodniecībā. Strādājot pedagog̣isko darbu Latvijas Universitātē, valodniece ir izstrādājusi vairākus teorētiskus un praktiskus kursus, kuros aplūkoti dažādi aktuāli valodas kultūras teorijas un prakses jautājumi. Svarīgākais no tiem ir kurss „Valodas kultūras pamati”, kas laika gaitā pārdēvēts par „Valodas kultūras teoriju”. Šis kurss noderēja par pamatu valodas kultūras teorijas izstrādei, kas apkopota monogrāfijā „Valodas kultūra teorētiskā skatīijumā” (Freimane 1993). Šì monogrāfija ir uzskatāma par pirmo un pagaidām plašāko šāda veida pētījumu latviešu valodniecībā. Tajā ietvertie teorētiskie jautājumi par valodas kultūru aplūkoti sistēmiski, nodrošinot pamatu attiecīgās zinātnes nozares izpratnei un turpmākai attīstībai. I. Freimani var uzskatīt arī par konceptuālas valodas prakses materiālu analīzes sistēmas izstrādātāju valodas kultūras aspektā, jo valodniece ḷoti detalizēti ir analizējusi visdažādākās atkāpes no normas visos līmeņos, izmantojot atbilstošas metodes, un sakārtojusi tās vienotā sistēmā, cenšoties neizlaist nevienu tipisku atkāpju gadījumu, kas zināms valodas praksē. Lai sasniegtu šo mērķi, vairāk nekā piecpadsmit gadu laikā autore kopā ar studentiem ekscerpējusi un analizējusi valodas prakses materiālus, kā arī aplūkojusi normatīvajos ieteikumos minētos tipiskos atkāpju gadījumus. Arī šì valodas prakses materiāla analīzes sistēma aprakstīta jau pieminētajā I. Freimanes monogrāfijā.

\section{Darbs valodas kultūras jomā Latvijas Universitātē}

I. Freimane sāka strādāt Latvijas Universitātē (toreiz Pētera Stučkas Latvijas Valsts universitātē) 1967. gadā. Šajā laikā valodas kultūra kā atsevišķa zinātnes nozare Latvijā vēl nebija izveidojusies, tomēr daudzi svarīgi teorētiskie jautājumi, kas uzskatāmi par šìs nozares pamatu, bija iestrādāti un aplūkoti profesora Artura Ozola zinātniskajos darbos. 20. gs. 50.-60. gados A. Ozols pievērsās tādiem jautājumiem kā nacionālās valodas stratifikācija, valodas mutvārdu un rakstu forma, latviešu literārās valodas jēdziens, literārās valodas cilme un avoti, literāāās valodas normas un to specifika u. c. (par to sk. Urbanoviča 2009, 147-148). Līdz ar 20. gs. 60. gadu otro pusi valodniecībā aktīva uzmanība tika pievērsta arī valodas prakses jautājumiem normatīvā aspektā, ko popularizēja ikgadējs rakstu krājums „Latviešu valodas kultūras jautājumi”. Šajā laikā pamazām radās nepieciešamie priekšnoteikumi valodas kultūras kā zinātnes izveidei un attīstībai.

1978. gadā universitātē tiek izveidots kurss „Valodas kultūras pamati”, kura docēšana uzticēta I. Freimanei (par to sk. Urbanoviča 2009, 148-151). 
Kurss jau no paša sākuma tika veidots kā sistēmisks teorētisko jautājumu un prakses materiālu analīzes apkopojums, kurā liela uzmanība veltīta studentu patstāvīgām studijām un praktiskiem darbiem. I. Freimane norāda, ka kursa tapšanā viņa nav meklējusi paraugus nedz latviešu, nedz ārzemju tradīcijās, bet bijusi sava ceḷa gājēja - kopā ar studentiem analizējusi dažādus valodas piemērus un pamazām izstrādājusi noteiktu valodas prakses faktu klasificēšanas un analīzes sistēmu. Jau pēc diviem gadiem - 1980. gadā - tika publicēta pirmā brošūra „Metodiskie norādījumi praktiskajiem darbiem valodas kultūras pamatos” (Freimane 1980), kurā aprakstîta kursa koncepcija un galvenie uzdevumi studentu praktiskajiem darbiem (sk. 1. attēlu) ${ }^{2}$.

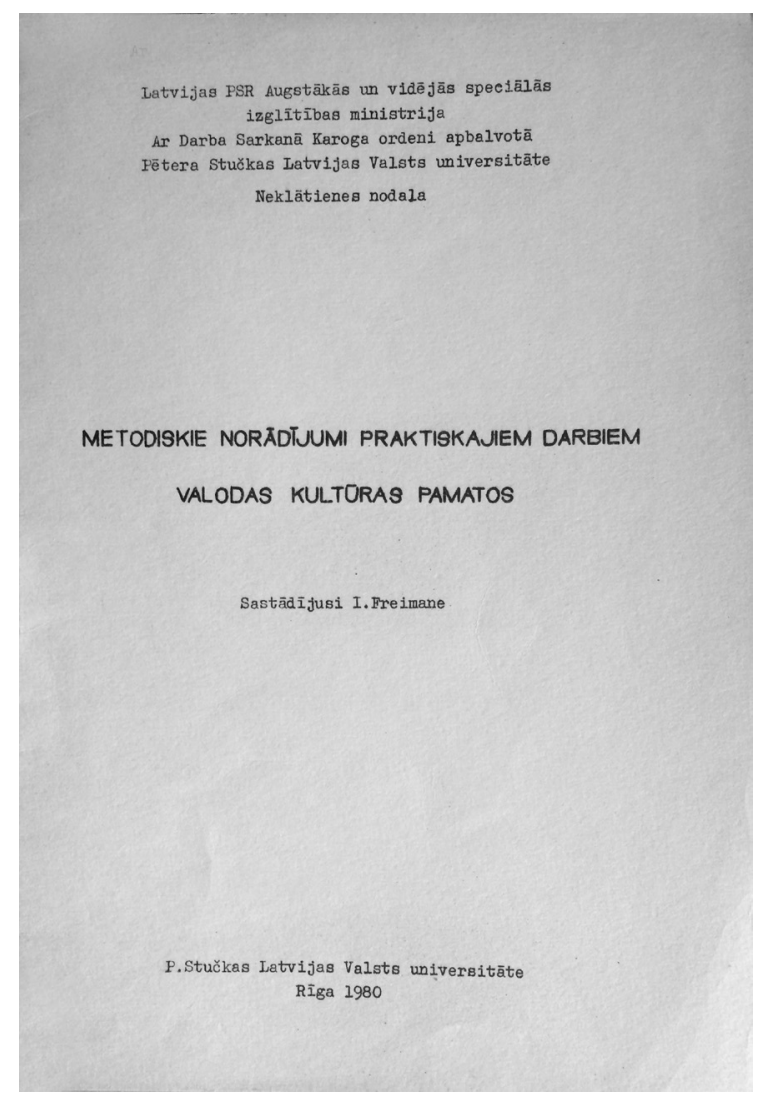

1. attēls. I. Freimanes sagatavotā brošūra „Metodiskie norādījumi praktiskajiem darbiem valodas kultūras pamatos" (1980).

2 Visi rakstā izmantotie attēli ir raksta autores oriğinālas fotogrāfijas, kas fotografētas 25.02.2017. 
Dažu gadu laikā šie norādījumi tika precizēti un izdoti atkārtoti ar nedaudz mainītu nosaukumu „Metodiskie norādījumi studentu patstāvīgajam darbam valodas kultūras pamatos” (Freimane 1985). Studentu patstāvīgajam darbam bija paredzētas vairākas darba formas (Freimane 1985, 3):

1) teorētiskās literatūras studijas un patstāvīga jautājumu gatavošana,

2) praktisku uzdevumu risināšana, izmantojot attiecīgus avotus,

3) valodas kḷūdu analīze un attiecīgas kartotēkas izveide.

Kursā „Valodas kultūras pamati” bija noteikts lekciju skaits, kuru laikā studentus iepazīstināja ar aktuāliem valodas kultūras teorijas problēmjautājumiem, piem., valodas kultūras izpratni, literārās valodas ${ }^{3}$ un literārās normas teoriju, valodas variatīvuma un paralēlismu teoriju. Teorētisko jautājumu izstrādē pamatā bija izmantota Prāgas lingvistiskās skolas koncepcija, kas vērsta uz funkcionāli normatīvās valodniecības attīstību un bija aktuāla un populāra tā laika kontekstā (par to sk. Urbanoviča 2009, 145-146). Teorētiskos jautājumus studenti gatavoja, apgūstot lekciju kursu (pēc kursa programmas), kā arī patstāvīgi lasot ieteikto literatūru un pēc tās gatavojot norādītos tematus (sk. Freimane 1985, 3). Nozīmīgu kursa dậu veidoja praktiskās nodarbības un studentu patstāvīgais darbs. Semināru un praktisko nodarbību laikā tika analizēts plašs valodas prakses piemēru skaits, turklāt katrs neprecizitātes labojums bija jāpamato ar atsauci uz konkrētu normatīvo literatūru. Lai studentam būtu vieglāk izpildīt šīs prasības, metodisko norādījumu brošūrā tika ieskicēti svarīgākie temati un kontroles uzdevumi praktiskajiem darbiem, kurus papildināja atsauces uz konkrētu valodniecisko literatūru (sk. Freimane 1985, 4-12). Tāpat kursā bija paredzēti vairāki patstāvīgi sagatavojami semināri, kuru temati, kā arī izmantojamās literatūras saraksts bija atrodami brošūras otrajā nodalāa (sk. Freimane 1985, 13-19).

Kursa apguves laikā katrs students izstrādāja arī individuālo darbu - kartotēku -, kurā ekscerpēja dažādas valodas prakses nepilnības, centās tās labot un teorētiski pamatot labojuma nepieciešamību. Kartotēkas izstrādes prasības bija aprakstītas brošūras trešajā nodạ̦ā (sk. Freimane 1985, 20-29). Kad kartotēka bija izstrādāta, tā tika iesniegta pārbaudei, un pēc tam students saṇēma darbu otrreizējai apstrādei - bija jāizlabo un jāpapildina nepilnības. Dažkārt gadījās, ka studentam kartotēkas labošana bija vēl sarežǧìtāka un laikietilpīgāka nekā oriğināla izstrāde, jo I. Freimane ḷoti rūpīgi pārbaudīja katru studenta ekscerpēto piemēru un stingri prasīja precīzi izskaidrot katru nepilnību. Šì pārbaudes forma ir saglabāta kursa pārbaudījumos līdz pat mūsdienām un tiek īstenota vairākās augstskolās, kurās docē valodas kultūras kursu.

Kopumā jāatzīst, ka „Valodas kultūras pamati” no studenta viedokḷa bija informatīvi piesātināts un individuālām studijām bagāts, līdz ar to arī pietie-

\footnotetext{
Šajā rakstā izmantots I. Freimanes lietotais termins „literārā valoda” un netiek risināts jautāiums par termina izpratni latviešu valodniecībā.
} 
kami grūts un darbietilpīgs studiju kurss, tomēr tas stiprināja studentu zināšanas un palīdzēja sistematizēt to mācību vielu, kas tika apgūta citos kursos saistībā ar mūsdienu literāro valodu. Lielākie nopelni šajā ziņā ir kursa docētājai I. Freimanei, kas izveidoja un uzturēja kursa programmu un aprakstītās prasības, kā arī skrupulozi vērtēja katra studenta sniegumu kursa kontekstā. Aprakstîtās kursa prasības izstrādātas 20. gs. 70. gados, un tās tika pilnā mērā īstenotas līdz pat gadsimta beigām, kamēr vien šo kursu docēja I. Freimane.

Pati I. Freimane norāda, ka vienmēr ir l̦oti nopietni un ar cieņu izturējusies pret studentu paveikto - ja students ir izpildījis viņam uzdotu darbu, tad pasniedzēja uzdevums ir to ļoti rūpīgi pārbaudìt un izteikt attiecīgi pamatotu vērtējumu. Un kaut arī studentu patstāvīgo darbu pārbaude bija l̦oti grūts un dažkārt arī neauglīgs process, tomēr valodniece šo laiku atceras ar prieku viņai ļoti patika darbs ar studentiem, kas bija ne tikai liels pašatdeves, bet arī iedvesmas un uzmundrinājuma avots.

\section{Monogrāfija „Valodas kultūra teorētiskā skatījumā”}

Laika gaitā krājās pieredze un izpratne par dažādiem valodas kultūras jautājumiem, turklāt arī savāktais valodas prakses materiāls pakāpeniski tika sakārtots noteiktā sistēmā un aprakstīts. 1993. gadā izdevniecība „Zvaigzne” publicēja I. Freimanes sagatavoto mācību līdzekli latviešu valodas specialitātes studentiem „Valodas kultūra teorētiskā skatījumā” (Freimane 1993) (sk. 2. attēlu).

Tã ir apjomīga 470 lappušu grāmata, kurā autore ir izstrādājusi valodas kultūras teorētiskos pamatus apkopojumā ar dažādiem valodas prakses materiāliem. Darbs sadalīts 4 galvenajās nodaḷās, kuras katra ir sīki izstrādāta vairāku pakāpju apakšnodalāās, un kopumā darbam ir vairāk nekā 300 apakšnodaḷu. Grāmatas beigās dots plašs citētās literatūras saraksts, kurā ieklạuts ap 400 vienību. Mācību līdzeklis ir bagātināts ar plašu valodas prakses materiālu - piemēriem no grāmatām, televīzijas un radio pārraidēm, preses un normatīviem avotiem. Kopumā ekscerpēts apmēram 15000 vienību (Freimane 1993, 440). Valodas prakses materiāla analīzē izmantota noteikta metodolog̣ija: „Lingvistiskajā analīzē ņemta vērā satura un formas vienība, par galveno uzskatot semantiku, nozīmi. Pētījumā izmantota galvenokārt lingvistiskā apraksta metode, kas kombinēta ar dažādiem elementiem un paņēmieniem no citām metodēm. Piem., ir konstatētas valodas vienību distributīvās īpašības, to segmentācijas un substitūcijas iespējas viena līmeņa ietvaros un integrālās attieksmes starp dažādu līmeņu parādībām; literārās valodas un tās normas teorijāa, it īpaši paralēlismu raksturošanā, izmantotas analoǵijas un opozīcijas; par leksiku, kontamināciju un līdzīgiem jautāiumiem runājot, izmantoti komponentu analīzes elementi. [..] Izmantoti arī transformācijas elementi.” (Freimane 1993, 4) 


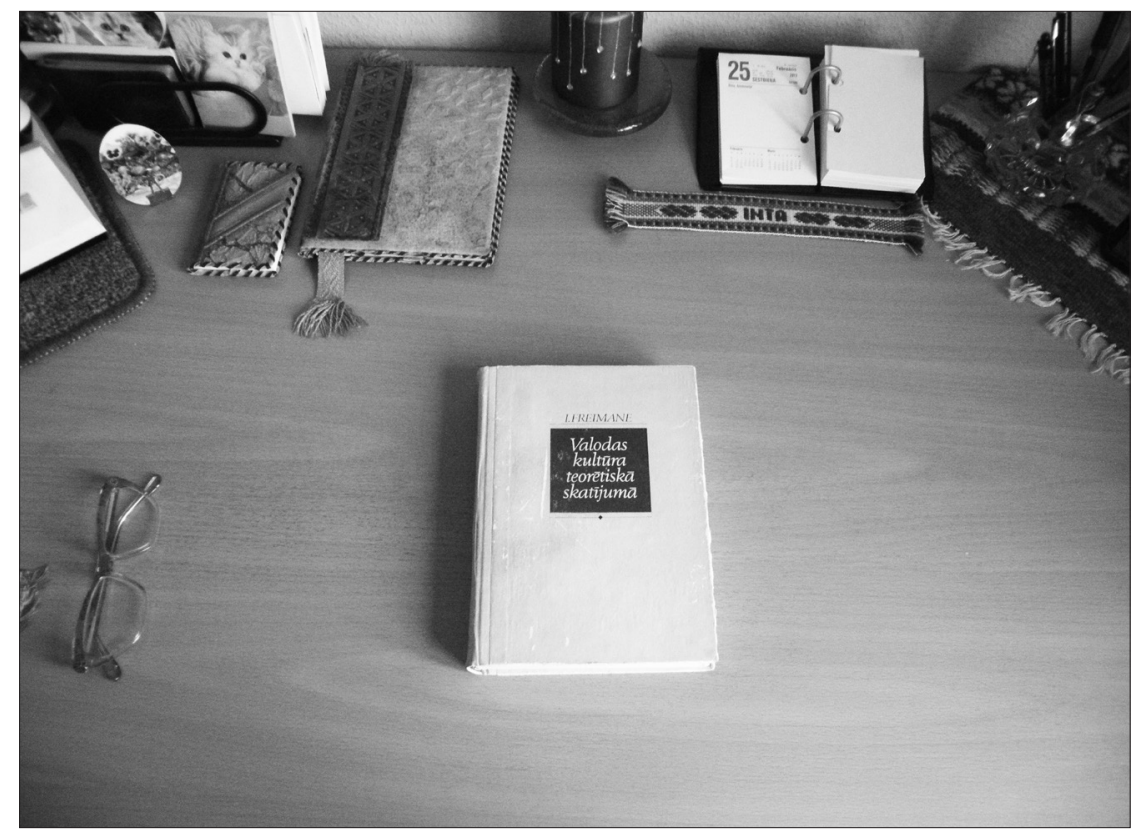

2. attēls. Monogrāfija „,Valodas kultūra teorētiskā skatījumā” (1993) uz I. Freimanes rakstāmgalda.

Monogrāfijā I. Freimane norāda, ka pirms viņas pētījuma latviešu valodniecībā nav zinātnisku darbu, kuros vienkopus būtu iztirzāti nozīmīgākie valodas kultūras teorijas un prakses jautājumi: „Latviešu valodniecībā pagaidām nav lielāku apkopojošu, sistēmisku pētījumu valodas kultūras teorijā; ir gan izvirzīti galvenie jēdzieni, piem., ir runāts par literārās normas kritērijiem un avotiem (J. Endzelīns, T. Porīte), par valodu kontaktiem un aizguvumu normēšanu (A. Ahero, A. Blinkena), par valodu plānošanas jautājumiem (K. Karulis) un citiem teorijas jautājumiem. Turklāt izstrādāts l̦oti daudz zinātniski pamatotu ieteikumu valodas praksē. Tie sakņojas tradīcijās, kas iedibinātas gadsimtu mijā, galvenokārt K. Mīlenbaha un J. Endzelīna darbos.”4 (Freimane 1993, 8-9)

Arī šoreiz valodniece nav meklējusi paraugus sava darba izstrādei - monogrāfija ir orig̣ināldarbs, kurā izveidota piln̄̄gi jauna valodas prakses materiālu analīzes sistēma, kas ir unikāla, un tāpēc tajā bijis grūti iekḷaut citu valodnieku izstrādātās piemēru klasifikācijas. I. Freimane atceras, ka grāmata tapusi

4 Te un turpmāk citātos saglabāta oriǵināla ortogrāfija, bet nav atstāti citātos lietotie oriǵinālie izcēlumi un parinžu norādes. 
apmēram 15 gadu laikā, un tās pamats ir kursā „Valodas kultūras pamati” izveidotā valodas prakses piemēru kartotēka (sk. 3. attēlu).

Mācību līdzekḷa pirmā nodaḷa „Valodas kultūra kā zinātnes nozare” veltīta vispārīgiem valodas kultūras jautājumiem, kuru pamatā ir valodas funkcionālā daba, proti, aprakstītas valodas funkcijas, valodas kultūra aplūkota valodas un runas šķ̄īumā, kā arī iztirzāta valodas kultūras nozīme indivīda un sabiedrības attīstības aspektā, raksturoti valodas kultūras līmeņi un valodas kultūras saistība ar citām zinātņu nozarēm. Grāmatas otrā nodaḷa „Valodas kultūras teorijas pamatjautāiumi” ietver tos būtiskos jautājumus, kas veido valodas kultūras kā zinātnes teorētisko pamatu. Šì nodaļa ir patiesi vērtīgs devums valodas kultūras attīstībā, jo ne tikai iezīmē galvenos valodas kultūras teorijas jautājumus, bet piedāvā sistēmisku zinātnes nozares koncepciju.

Trešā grāmatas nodaḷa „Funkcionālas atkāpes no latviešu literārās valodas normām teorētiskā vērtējumā” veltīta valodas prakses jautājumiem, un uzmanība pievērsta galvenokārt dažādām atkāpēm no literārā standarta. Šì ir grāmatas plašākā nodaḷa, kurā funkcionālās atkāpes skatītas noteiktā sistēmā un katram neprecizitāšu tipam dots gan bagātīgs piemēru klāsts, gan arī skaidrojums,

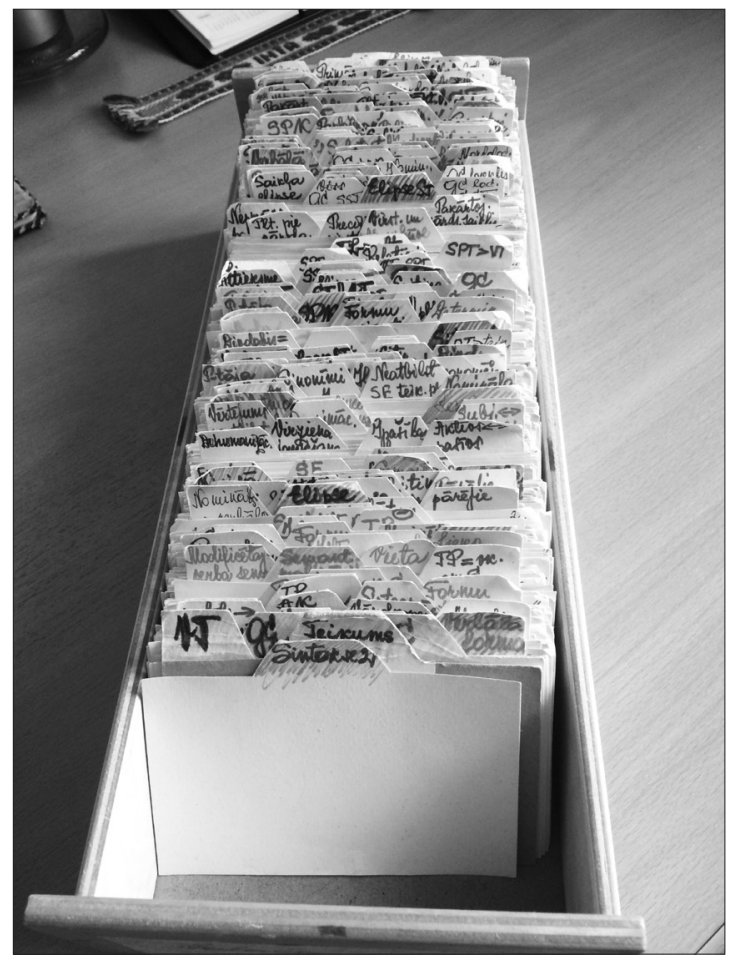

3. attēls. I. Freimanes izstrādātās kartotēkas sintakses daḷa. 
pamatojoties uz normatīvajiem ieteikumiem. Darba autore norāda, ka „galvenais mērkisis ir parādīt iespējamās atkāpes no literārās valodas normām, veidojot noteiktu sistēmu, un sniegt ieteikumus" (Freimane 1993, 440). Grāmatas ceturtā nodạ̧a „Valodas līdzekḷ̂u funkcionālā aprite” ir l̦oti īsa, tomēr tā iezīmē funkcionālās lingvistikas, līdz ar to arī valodas kultūras, specifiku valodas attīstībā un plānošanā.

Grāmatas ievadā I. Freimane $(1993,4)$ norāda, ka mācību līdzeklis paredzēts profesionāli sagatavotam lasītājam, kam ir zināmi valodniecības teorijas pamati visā mūsdienu latviešu literārās valodas sistēmā, un nav domāts izmantošanai praktiskos nolūkos kā valodas prakses rokasgrāmata. Tomēr laika gaitā grāmata ir ieguvusi plašu lietotāju loku: to izmanto akadēmiķi un jaunie zinātnieki, lai citētu kā autoritatīvu avotu; to izmanto studenti un viņu pasniedzēji, lai analizētu dažādas valodas kultūras aktualitātes; to izmanto skolās, īpaši vidusskolās, ja tiek aktualizēti normētās valodas jautāiumi; to izmanto arī žurnālisti, ierēdņi un citu profesiju pārstāvji kā valodas prakses rokasgrāmatu. „Koncentrētā izteiksme, sīkā, zinātniski pamatotā klasifikācija padara šo darbu par vērtīgu lasāmvielu filologiem un pamatu turpmākam - praktiskam un teorētiskam - darbam valodas kultūrā, bet bagātīgais faktu vākums un pamatotās rekomendācijas l̦auj to izmantot arī par rokasgrāmatu valodas praksē.” (Lokmane 2003, 163)

1993. gadā par šo monogrāfiju I. Freimanei pieškisirts habilitētā filolog̣ijas doktora grāds. Mūsdienās grāmata ir bibliogrāfisks retums, kas ir atrodams tikai lielākajās bibliotēkās, tāpēc ḷoti vērtīgi, ka grāmatas materiāls ir pieejams elektroniski, proti, Valsts valodas komisijas mājaslapā ir publicētas nozīmīgākās I. Freimanes grāmatas nodaḷas (sk. http://www.vvk.lv/?sadala=154). Autorei vairākkārt piedāvāja sagatavot otro grāmatas izdevumu, tomēr I. Freimane uzskatījusi, ka darbs ir padarīts un otrais izdevums būtu jāveido jau pilnīgi citāds, atbilstošs mūsdienu valodas attīstības tendencēm, tāpēc tam būtu jābūt jau pavisam citam pētījumam ar citu pieeju un citiem piemēriem.

\section{Valodas kultūras teorijas konceptuālais pamats}

Balstoties uz A. Ozola iestrādēm un idejām, I. Freimane ir izveidojusi valodas kultūras kā zinātnes teorētisko pamatojumu latviešu valodniecībā. Kā jau iepriekš tika minēts, tās pamatā ir čehu lingvistiskās skolas idejas, kas izstrādātas 20. gs. pirmajā pusē un laika gaitā kḷuvušas populāras daḷā Eiropas, kā arī krievu valodniecībā. N̦emot vērā tā laika kontekstu un nostādnes latviešu valodniecībā, valodas kultūra kā zinātnes nozare bija aktuāla nepieciešamība, lai pilnīgotu, stiprinātu un uzturētu normētu nacionālās valodas paveidu - literāro valodu. Sākotnēji normētais valodas paveids bija paredzēts valodas rakstu formai, tomēr ar laiku tas tika lietots, lai nodrošinātu ne tikai 
rakstveida, bet arī mutvārdu saziņu publiskajā sfērā - zinātnē, publicistikā, lietiškajā vidē u.tml. Tas rosināja dažādu teorētisku jautājumu aktualizēšanu, piem., par minētā valodas paveida nozīmi valodas un sabiedrības attīstībā, par paveida robežām un normu izstrādes principiem. Šos un citus jautājumus I. Freimane aktualizējusi un sakārtojusi vienotā sistēmiskā kopumā, kas mūsdienās veido valodas kultūras kā zinātnes nozares pamatu.

$\mathrm{L} \overline{1} \mathrm{dz}$ ar I. Freimanes darbu valodas kultūras jomā latviešu valodniecībā ir stabilizējusies termina valodas kultūra izpratne. Pirmo reizi šis termins izvērsti ir skaidrots „Latvijas Padomju enciklopēdijā”, kurā akcentēts, ka terminam ir divas nozīmes - pirmkārt, tā ir prasme izmantot valodas izteiksmes līdzekḷus atbilstoši valodas situācijai, un, otrkārt, tā ir teorētiska un praktiska valodniecības nozare, kas pētī literārās valodas normalizācijas problēmas, valodas līdzeklı funkcionēšanas likumsakarības atbilstoši saziņas vajadzībām (sk. Jērāns 1987, 252). Š̄̄ šksirkḷa izstrādē un apspriešanā piedalījusies arī I. Freimane. Vēlāk savā monogrāfijā ,Valodas kultūra teorētiskā skatījumā" I. Freimane (1993, 5) papildina termina valodas kultūra definīciju: „Valodas kultūras izpratne ir divējāda. Pirmkārt, parasti ar valodas kultūru tiek saprasta kopta valoda, resp., literārās valodas normu zināšanas un prasme tās izmantot gan mutvārdos, gan rakstveidā; tās ir izrunas, vārdlietojuma, gramatikas un citas likumības. Turklāt valodas kultūra tiek saistīta arī ar prasmi izmantot izteiksmīgus valodas līdzekḷus dažādos saziņas apstākļos atbilstoši valodas lietotāju mērķiem un izteikuma saturam. [..] Otrkārt, valodas kultūra ir arī zinātnes nozare, kur tiek pētītas attiecīgās zināšanas un prasmes." Tai pašā monogrāfijā I. Freimane (1993, 15) vēl izcēlusi: „Tieši uz valodas meistarības līmeni būtu attiecināma valodas kultūras pamatizpratne, proti: valodas kultūra ir valodas līdzekḷu optimāls lietojums kādā noteiktā runas situācijā.” Līdzīga izpratne turpmāk ir iestrādāta arī „Valodniecības pamatterminu skaidrojošajā vārdnīcā” (sk. Skujiņa 2007, 419), kā arī atrodama akadēmiskajā terminu datubāzē AkadTerm (http://termini.lza.lv/ term.php).

Savā valodas kultūras koncepcijā I. Freimane izmantojusi funkcionālu pieeju valodai, turpinot A. Ozola iestrādāto pieeju valodas izpētē un valodas materiāla aprakstīšanā. I. Freimane $(1993,6)$ norāda: „Valoda funkcionē sabiedrībā un ir līdzeklis sociālu mērksu sasniegšanai. Valodas kultūras teorija nav iedomājama bez valodas funkcionāla raksturojuma - tieši valodai funkcionējot, rodas praktiski un teorētiski uzdevumi valodas kultūrā.” Teorētiskā aspektā uzmanība pievērsta galvenajām valodas funkcijām individuālās un sociālās organizēšanas sfērā, valodas funkcionālās izpētes aspektiem, valodas kultūras izpratnei valodas un runas šksīrumā, valodas kultūras lomai indivīda un sabiedrības attīstībā, valodas līdzekḷu funkcionālajai apritei un citiem jautājumiem. Praktiskā aspektā funkcionālu pieeju I. Freimane strikti ievērojusi 
valodas prakses materiālu analīzē, jo ,atkāpes no literārā standarta ir konstatējamas, tikai pētījot valodu funkcionāli" (Freimane 1993, 141).

Līdz ar funkcionālu pieeju viens no svarīgākajiem jautājumiem, ko teorētiskā aspektā aktualizējusi un aprakstījusi I. Freimane, ir nacionālās valodas polifunkcionālums. Viņas koncepcijā valodas kultūras jēdziens tiek paplašināts un attiecināts ne tikai uz literāro valodu, bet gan uz visu valodu kopumā. Īstenā valodas kultūra ir prasme apzināties konkrēto komunikatīvo situāciju un izvēlēties tai atbilstošus izteiksmes līdzekḷus, lai veicinātu konsituatīvi precīzu komunikāciju, līdz ar to nacionālajā valodā nevar aprobežoties vien ar literārās valodas zināšanām, bet ir jāapzinās tās dažādās eksistences formas. Un tomēr nacionālas valodas stratifikācijā mūsdienās nozīmīgāko lomu ieņem tieši literārā valoda, jo tā pamatā reprezentē nacionālo valodu gan runas, gan rakstu formā (Freimane 1993, 28), un tai ir raksturīgs vispārējs prestižs. I. Freimane jautājumu par literāro valodu ir aplūkojusi samērā plaši, pievēeršoties gan literārās valodas izpratnei, gan tās polifunkcionālumam, gan galvenajām attīstības tendencēm. I. Freimane $(1993,31)$ skaidri un precīzi akcentējusi literārās valodas nozīmi nacionālās valodas kontekstā: „Literārā valoda ir plašas sabiedrības saziņas līdzeklis ar īpašiem uzdevumiem: tā ir valdības aktu, zinātnes, publicistikas un kultūras valoda. Literārajai valodai ir īpaši sociāli uzdevumi: tā vieno nāciju, palīdz saglabāt nacionālo pašapziņu. Literārajā valodā tiek nostiprinātas un uzkrātas tautas kultūras vērtības un tradīcijas, vārda meistaru mantojums."

I. Freimane ir aktualizējusi arī valodas kodificēšanas jautājumus un izstrādājusi literārās normas teoriju. 20. gs. otrajā pusē jautājumu par literāro normu teorētiskā aspektā latviešu valodniecībā skatīiuši dažādi autori (sk., piem., Ozols 1967; Ceplītis 1978; Druviete 1982; Bušs 1987), un tas liecina par jautājuma aktualitāti attiecīgajā laika posmā. I. Freimane (1993, 39) uzskata, ka literārā norma ir valodas kultūras centrālais jautājums, tāpēc tai ir pievērsusies plašāk. I. Freimane ir izmantojusi gan čehu, gan krievu, gan igauņu valodnieku atziņas un uz to pamata analizējusi jautājumus par valodas normu tipologiiju, normas sakariem ar valodas sistēmu un ūzusu, normas dinamiskumu, literārās normas izpratni un kodifikāciju, kā arī izstrādājusi literārās normas principu hierarhisko sistēmu. Izstrādātā teorija ir diezgan vērienīgs teorētisko atziņu kopums, un iedziļināšanās tajā ir laikietilpīga un prasa zināmu zinātnisku briedumu, tomēr aizvien tā ir rosinošs avots diskusijām un jauniem pētìjumiem dažādās jomās un no dažādiem skatupunktiem.

Valodas kultūras teorijas attīstībā nozīmīgs ir arī I. Freimanes viedoklis par paralēli funkcionējošu valodas līdzekḷu nozīmi valodas attīstībā. I. Freimane ir izstrādājusi paralēlismu teoriju, kurā tādas paralēlismu apakšsistēmas kā varianti, sinonīmi, paronīmi, homonīmi savā starpā atrodas noteiktās attieksmēs. „Par paralēlismiem ir saukti tie valodas līdzekḷi visos līmeņos, kurus iespējams lietot paralēli, resp., kuru lietojumā iespējama izvēle: parasti 
valodas vienību realizācijā tiek izmantots viens no paralēlismiem. Izvēle var būt brīvāka vai kategoriskāka atkarībā no paralēlisma tipa un izteikuma veida. Veiksmīga paralēlismu izvēle un funkcionēšana ir literārās valodas un literārās normas attīstības pamatnosacījums. [..] Paralēlismu lietojums ir l̦oti svarīga valodas kultūras problēma. Prasme veiksmīgi izvēlēties paralēlismus attiecināma kā uz valodas meistarības izkopšanu (piem., iederīgu leksisko sinonīmu lietošana noteiktā valodas situācijā), tā arī uz pareizumu: kāds no paralēlismiem var būt pieļaujams (literārie vārdformu varianti) vai nevēlams (nevēlama varianta lietošana normatīivā varianta vietā, neprecīza paronīma lietošana, homogrāfu jaukšana izrunā u.tml.).” (Freimane 1993, 82-83) Paralēlismi skatīti konsekventā sistēmā, tā radot vienotu kopainu par paralēlismu sistēmismu gan no formālā, gan arī no semantiskā viedokḷa.

Saistībā ar paralēlismu teoriju minams arī valodas līdzekḷu funkcionālās aprites jautāiums, ko I. Freimane (1993, 434) ir ieskicējusi. „Visi valodas līdzekḷi pastāvīgi mainās un attīstās. Ir trīs galvenās valodas līdzekḷu attīstības fāzes: 1) valodas līdzekḷu tapšana - vārddarināšana, konstrukciju veidošana un aizgūšana; 2) funkcionēšana - valodas līdzekḷu izmantošana un 3) relatīvi pasīvs valodas līdzekḷu krājums, resursi. Resursi savukārt var tikt izmantoti valodas līdzekḷu tapšanā, parasti gan jaunā kvalitātē. Tā veidojas valodas līdzekḷ̣u funkcionālā aprite.” Šàda valodas līdzekḷ̣u aprite palīdz nodrošināt valodas polifunkcionālumu, tāpēc valodas prakses speciālistu uzdevums ir apzināt un regulēt valodas līdzekḷu vietu aktuālajā lietojumā, kā arī nodrošināt ilgtspèjīgu valodas attīstību. Valodas paralēlums ir tas valodas kultūras teorijas jautājums, ko I. Freimane turpinājusi risināt arī citos savos pētījumos (sk., piem., Freimane 1999, 2014, 2017).

\section{Valodas prakses materiālu sistēmiskā analīze}

Darbojoties valodas kultūras jomā, I. Freimane kopā ar studentiem ilgstoši veidojusi kartotēku, kurā analizētas dažādas valodas prakses nepilnības. Kā jau iepriekš tika minēts, liela daļa šo piemēru apkopoti monogrāfijā „Valodas kultūra teorētiskā skatījumā”, kurā tie sakārtoti noteiktā sistēmā un analizēti pēc vienotiem principiem. Marta Rudzìte $(1994,54)$ raksta par I. Freimanes darbu: „Patiesībā jāapbrīno autores izstrādātā analīzes sistēma un izvērtētā valodas materiāla daudzums. Te nu I. Freimane apliecinājusi savas zināšanas visos mūsdienu latviešu literārās valodas līmeņos.” Pati I. Freimane uzskatījusi, ka izveidot tik apjomīgu un detalizētu valodas faktu klasifikāciju un analīzi viņai ir izdevies tikai tāpēc, ka pedagog̣iskās darbības laikā bija jāsagatavo un jādocē daudzi dažādi kursi, kas saistāmi ar visu valodas līmeņu izpēti. I. Freimane ir docējusi baltu filolog̣ijas studentiem tādus kursus kā mūsdienu latviešu literārās valodas sintakse, valodas kultūras pamati, valodas kultūras teorija, latviešu 
interpunkcija, kā arī speciālkursus par verbu valenci, skaņu verbiem, aktuāliem vienkārša teikuma sintakses jautājumiem un leksikogrāfiju, savukārt citu specialitāšu studentiem sagatavoti tādi kursi kā fonētika, ortoepija, grafētika, ortogrāfija, morfolog̣ija (Lokmane 2003, 161-162; Bankavs, Jansone 2010, 135).

Valodas prakses materiāla aprakstā I. Freimane izmantojusi gan tradicionālās apraksta metodes, gan arī tam laikam ne tik populārus paņēmienus kā transformācija, substitūcija u. c. „Izmantoti galvenie lingvistiskās analīzes postulāti: materiāls analizēts valodas sistēmas un struktūras, sintagmātisko un paradigmātisko attieksmju, statiskā un dinamiskā, sinhroniskā un nepieciešamības robežās arī diahroniskā aspektā.” (Freimane 1993, 3)

Piemēru analīze liecina, ka atkāpes no literārās valodas normas jebkurā valodas līmen̄i var būt: 1) formālas, ja valodas praksē netiek izmantots literārās valodas kodificētais variants, 2) semantiskas, ja valodas līdzeklis denotatīvi neatbilst konsituācijai, 3) stilistiskas, ja valodas līdzeklis konotatīvi neiederas konsituācijā. I. Freimane norāda, ka svarīgākais ir semantiskais aspekts, un semantikas loma valodas sistēmā pieaug virzienā no zemākā uz augstāko valodas līmeni (Freimane 1993, 141). Pēc dažādu atkāpju analīzes I. Freimane secina, ka galvenie atkāpju tipi latviešu valodas sistēmā ir: 1) kāda vajadzīga, nepieciešama valodas līdzekḷa trūkums vai nepilnība, 2) valodas līdzekḷu pārdaudzums vai lieki valodas līdzekḷi kādā valodas vienībā un 3) valodas līdzekḷu nemotivēta sajaukšana, savstarpēji nomaināmi valodas līdzekḷi (Freimane 1993, 142). Vislabāk šo trīs atkāpju tipu analīze ir vērojama monogrāfijas „Valodas kultūra teorētiskā skatījumā” vārddarināšanas un leksikas nepilnību apskatā (sk. Freimane 1993, 151-197).

Valodas prakses materiāli pamatā dalīiti divās lielās grupās: 1) ar funkcionālām atkāpēm saistīti iekšèjās attīstības procesi un 2) ar funkcionālām atkāpēm saistīti aizgūti valodas līdzekḷi. Pirmajā grupā ietvertas un analizētas tās atkāpes no latviešu literārās valodas normas, kas ir izveidojušās valodas iekšèjās attīstības ietekmē, proti, atkāpes no ortoepijas, gramatikas un stilistikas normām. Ortoepijas jautājumi ir ieskicēti nedaudz, tomēr tie ir sistēmiski pārskatāmi. Samērā plaši ir aprakstīta vārddarināšana valodas praksē, pievēršoties ne tikai atkāpēm dažādu valodas vienību darināšanā, bet arī darinājumu stilistiskajam lietojumam konsituācijas ietekmē. Turpretī leksikas nepilnības I. Freimane $(1993,193)$ analizējusi ḷoti îsi, norādot, ka latviešu valodas leksika ir pamatīgi pētīta citos darbos un inventarizēta vispārīga tipa vārdnīcās. Vienīgā leksikas grupa, kam autore pievērš uzmanību valodas kultūras aspektā, ir termini (sk. Freimane 1993, 296-303). Ļoti plaši aplūkotas dažādas gramatiskas atkāpes no literārās valodas normas, šķirot formveidošanas nepiln̄ibas no sintakses vienību izveides nepilnībām, kaut arī piemēru analīze liecina, ka šie jautājumi ne vienmēr ir diferencējami, jo formveidošana lielā mērā pilnvērtīgi îstenojas tieši sintaktiskajās konstrukcijās. Atsevišķi 
valodas kultūras aspektā ir aplūkoti stilistiski izmantotie valodas līdzeklịi, un šajā apakšnodaḷā īpaši vērtīga ir dažādu pārspīlējumu analīze.

Otrajā pamatgrupā analizēti aizgūtie valodas līdzekḷii, un dots to vērtējums no valodas kultūras viedokḷa. I. Freimane ir pievērsusies gan aizguvumu pielāgošanas, gan lietošanas jautājumiem. Liela uzmanība veltīta kalku aprakstam, koncentrējot uzmanību uz valodā nevēlamu kalku analīzi un aizstāšanas iespējām. Analizējamo piemēru lielais skaits liecina par šīs problēmas aktualitāti pagājušā gadsimta otrajā pusē. I. Freimanes piedāvātā kalku klasifikācija ir l̦oti plaša un detalizēta, un tajā ir diezgan grūti orientēties, īpaši tajos gadījumos, ja nepieciešams atrast skaidrojumu par kādu konkrētu, iespējams, valodā ḷoti bieži lietotu nevēlamo kalku, tomēr tajā pašā laikā tas ir vērtīgs materiāls, kurā lasītājs var meklēt atbildes uz dažādiem valodas prakses jautājumiem, kā arī gūt rosinājumu līdzīgu problēmu aktualizēšanai.

\section{Secinājumi}

Pateicoties I. Freimanes ilgstošajam pētnieciskajam un pedagogீiskajam darbam, latviešu valodniecībā var runāt par valodas kultūru kā zinātni, kam ir savs teorētiskais, metodoloğiskais un arī praktiskais pamats, turklāt tā ir nostiprināta arī pedagog̣iskajā praksē. Valodas kultūras zinātnes galvenie teorētiskie jautājumi ir sistēmiski sakārtoti un zinātniski pamatoti aplūkoti monogrāfijā „Valodas kultūra teorētiskā skatījumā”, iezīmējot dažādus virzienus turpmākajiem pētījumiem un diskusijām. Izveidota arī ląti detalizēta valodas prakses materiālu sistēmiskā analīze. Tā var noderēt kā ierosmes avots ḷoti dažādiem pētījumiem, jo ietver visu valodas līmeņu vienības.

Kopš I. Freimanes monogrāfijas publicēšanas ir pagājis gandrīz ceturtdaḷgadsimta, un no mūsdienu viedokḷa daudzi tur aplūkotie jautājumi ir ieguvuši citu kvalitāti, tāpat arī daudzi analizētie piemēri vairs nav aktuāli vai arī ir kḷuvuši par stabilu literārās normas dạ̣u, tomēr tas nemazina I. Freimanes devumu latviešu literārās valodas kopšanas laukā. Viņas darbus raksturo plašs un oriǵināls, un tajā pašā laikā zinātniski pamatots skatījums, stingra sistēmiskā pieeja, kā arī savam laikam novatoriskas atziņas, kuras var attīstīt tālāk un par kurām var diskutēt arī mūsdienās.

\section{Literatūra}

1. Bankavs, Andrejs, Jansone, Ilga. 2010. Valodniecība Latvijā: fakti un biogrāfijas. Rīga: LU Akadēmiskais apgāds.

2. Bušs, Ojārs. 1987. Valodas norma un kodificētā norma. Valodas aktualitātes 1986. Rìga: Zinātne, 114-116. 
3. Ceplītis, Laimdots. 1978. Latviešu valodas stāvoklis un attīstība mūsdienās. Latviešu valodas kultūras jautājumi. 14. Rīga: Liesma, 16-27.

4. Druviete, Ina. 1982. Valodas normas jēdziena interpretācija. Latviešu valodas kultūras jautājumi. 18. Rīga: Avots, 12-22.

5. Freimane, Inta. 1980. Metodiskie norādījumi praktiskajiem darbiem valodas kultūras pamatos. Rīga: P. Stučkas Latvijas Valsts universitāte.

6. Freimane, Inta. 1985. Metodiskie norādījumi studentu patstāvīgajam darbam valodas kultūras pamatos. Rīga: P. Stučkas Latvijas Valsts universitāte.

7. Freimane, Inta. 1993. Valodas kultūra teorētiskā skatījumā. Rīga: Zvaigzne.

8. Freimane, Inta. 1999. Rol' parallelizmov v oborote jazykovyh sredstv. Leksika socialinès raidos atspindys: Konferencijos pranešimai. Kaunas: Technologija, 29-39.

9. Freimane, Inta. 2014. Valoda semantiski funkcionālā aspektā. Valoda: nozīme un forma. 5. Opozīcijas sintaksē un semantikā. Kalnača, Andra, Lokmane, Ilze (red.). Rịga: LU Akadēmiskais apgāds, 33-61.

10. Freimane, Inta. 2017. Variatīvuma loma valodas līdzekḷu apritē. Semantika. Sintakse. Valodas kultūra. Kalnača, Andra, Lokmane, Ilze (red.). Rīga: LU Akadēmiskais apgāds.

11. Jērāns, Pēteris (galv. red.). 1987. Latvijas Padomju enciklopēdija. 10 1 . Rīga: Galvenā enciklopēdiju redakcija.

12. Lokmane, Ilze. 2003. Intai Freimanei - 70. Baltu filologiija. XII (1). Rīga: Latvijas Universitāte, 161-163.

13. Ozols, Arturs. 1967. Raksti valodniecībā. Rīga: Zinātne.

14. Rudzīte, Marta. 1994. Inta Freimane. Valodas kultūra teorētiskā skatīiumā. Rīgā, „Zvaigzne”, 1993. 470 lpp. Baltu filoloǵija IV. Rīga: Latvijas Universitāte, 50-55.

15. Skujiņa, Valentīna (red.). 2007. Valodniecības pamatterminu skaidrojošā vārdnīca. Rīga: LU Latviešu valodas institūts.

16. Urbanoviča, Inta. 2009. Valodas kultūra kā studiju priekšmets Latvijas Universitātē. Filoloǵijas un mākslas zinātnes Latvijas Universitātē 1919-2009. Procesi un personības. Rīga: Latvijas Universitāte, 145-152.

17. http://www.vvk.lv/?sadala $=154$

18. http://termini.lza.lv/term.php

\section{Summary}

This paper focuses on the main lines of activity of Inta Freimane in the area of culture of language in Latvian linguistics. She works in this field for more than 40 years and it is reasonable to say that I. Freimane has created culture of language as a branch of science. First of all, I Freimane has developed an academic course for high schools, which is included basic theoretical concept of culture of language and some questions about language practice analysis. These ideas are included into the monograph „Valodas kultūra teorētiskā skatījumā” published in 1993. I. Freimane has developed a conceptual framework of culture of language that has been created on the basis of Czech functional linguistics ideas, and she has classified materials of language practice in structured system. 